\title{
필리핀 개발포럼 후속회의 결과
}

\section{I . 핵심사항}

밀ㄹ리핀 개발포럼회의가 7.4(월) 마닐라에서 필리핀 정부관계자, 원조공여국 및 국제기구 대표 등 100 여 명이 참석한 가운데 개최되어 지난 3.7 8간 다 바오 개최 원조공여국회의에서 논의된 5 개 분야에 대한 필리핀정부의 개혁추진 현황을 점검함.

\section{II. 각 주제별 발표요지}

\section{1. 사회발전(Social Progress)}

-Corazon Juliano N. Soliman 사회복지개발부 장관 발표

ㅁㅣㅣㄹ리핀정부의 천년개발목표(MDGs) 달성을 위한 노력의 일환으로 보건, 교육 분야에 대한 개혁을 추 진하고 있으며, 특히 학교급식 지원과 기초교육 개 혁(School First Initiative)을 중점 추진하고 있음.

\section{2. 성장과 투자}

(Growth and Investment Climate)

-Elmer Hernandez 통상투자부 차관 발표

ㅁ 1/4분기중 필리핀 투자 유치 실적은 전년 동기보다 감소하였으며, 인프라 건설분야가 $80 \%$ 를 차지하 였으며, 광산개발 분야도 증가추세를 보임. 동 기 간 동안의 주요 투자국은 일본과 한국이라고 밝힘. 민행ㅇ중인 주요 프로젝트는 마닐라근교 고속도로 연장 및 확장, 바탕가스 항구개발, 수빅-클라크 간 고속도로 건설 등의 사업임.

밀ㄹ리핀의 주요 투자 유치분야는 건축자재, ICT, 식품, 전자, 자동차, 조선, 해운 등의 분야라고 언 급함.

\section{3. 경제 및 재정개혁}

(Economic and Fiscal Reforms)

- Gil S. Beltran 재정부 차관보 설명

ㅁ 금년 5월까지 세수 P3,223억, 세출 P3,901억으로 


\section{I . 핵심사항}

밀ㄹ리핀 개발포럼회의가 7.4(월) 마닐라에서 필리핀 정부관계자, 원조공여국 및 국제기구 대표 등 100 여 명이 참석한 가운데 개최되어 지난 3.7 8간 다 바오 개최 원조공여국회의에서 논의된 5 개 분야에 대한 필리핀정부의 개혁추진 현황을 점검함.

\section{II. 각 주제별 발표요지}

\section{1. 사회발전(Social Progress)}

-Corazon Juliano N. Soliman 사회복지개발부 장관 발표

ㅁ필리핀정부의 천년개발목표(MDGs) 달성을 위한 노력의 일환으로 보건, 교육 분야에 대한 개혁을 추 진하고 있으며, 특히 학교급식 지원과 기초교육 개 혁(School First Initiative)을 중점 추진하고 있음.

\section{2. 성장과 투자}

\section{(Growth and Investment Climate)}

-Elmer Hernandez 통상투자부 차관 발표

ㅁ 1/4분기중 필리핀 투자 유치 실적은 전년 동기보다 감소하였으며, 인프라 건설분야가 $80 \%$ 를 차지하 였으며, 광산개발 분야도 증가추세를 보임. 동 기 간 동안의 주요 투자국은 일본과 한국이라고 밝힘. 민행중인 주요 프로젝트는 마닐라근교 고속도로 연장 및 확장, 바탕가스 항구개발, 수빅-클라크 간 고속도로 건설 등의 사업임.

ㅁ필리핀의 주요 투자 유치분야는 건축자재, ICT,
식품, 전자, 자동차, 조선, 해운 등의 분야라고 언 급함.

\section{3. 경제 및 재정개혁}

\section{(Economic and Fiscal Reforms)}

-Gil S. Beltran 재정부 차관보 설명

ㅁㅡㅡㅁ년 5월까지 세수 P3,223억, 세출 P3,901억으로 $\mathrm{P} 678$ 억 적자이나 당초 계획보다는 적자폭이 줄어듬. 믐년 5월 24일 부가가치세 법안이 통과되었으며, 등록세 개혁이 검토되고 있고, 세무행정 효율화를 위한 각종 방안 추진, 탈세방지를 위한 각종조치 및 밀수대책반을 운영 등임.

-기타 재정부문 개혁의 일환으로 자본시장 활성 화를 위한 제도개선, 연금 관리제도 개선, 정부 지출의 효율화 등이 추진중에 있음.

ㅁ 이와 관련, 재정안정 프로그램(2010년까지 균형재 정 달성)을 위해서는 7 월 1 일 대법원의 결정에 의 해 실행이 보류된 부가가치세(Expanded VAT) 인 상법안이 조기 시행되어야 하나 대법원의 7 월 1 일 자 잠정 보류결정은 1 일 1 억 3 천만 페소의 세수감 소를 가지고 왔으며 이로 인해 금년도 적자 축소 목표액인 1600억 페소 적자달성은 어려우나 동 대 법원 결정이 2 개월 내에 취소될 것으로 전망함.

\section{4. 통치 및 부패방지}

\section{(Governance and Anti-Corruption)}

-Merciditas Gutierrez 대통령실 부패방지위원 회 위원장 설명

ㅁㅣㅣㄹ리핀의 부패방지를 위한 정책으로 (1)부처 내 부 
패방지 대책 (2)부처간 협력강화 (3)제도개선을 통 한 부패방지 (4)부패방지 실적 평가 및 관리 (5)부 패방지 홍보 등 5 개 방안을 마련하고 각 방안별 프 로그램을 실행중임.

\section{5. 지방자치}

\section{(Decentralization and Local Government)}

- Benito Catindig 내무지방자치부 차관보 설명 마나정적인 지방자치제 운영을 위해서 (1)지방정부 공무원의 능력 강화, (2)지방정부 재정능력 향상, (3) 정책개발 및 운영능력 개선이 급선무이며, 각 부문별로 구체적인 프로그램을 실행중임.

ㅁㅡㅡㄱㅎㅣ, 세계은행의 재정 및 기술원조로 '지방정부 재정지원 대책' 에 관한 연구사업이 진행중임을 언급

\section{6. 원조공여국 주요언급 요지}

ㅁ원조공여국 및 국제기구 참석자들은 필리핀정부 의 각 분야별 개혁노력을 평가하고 동 개혁의 성공 적인 추진을 위한 필리핀정부의 각별한 노력을 강 조함.

- 일본측 대표는 필리핀 세수의 효율적인 징수가 재정안정에 중요함을 언급하였고, 외국 투자자 들에 대한 부가가치세 환급에 대한 필리핀정부 의 노력을 촉구

-미국측 대표는 필리핀 부패방지를 위한 노력에 민간부문의 적극적인 참여 유도가 필요하다고 언급하였으며, 호주 대표는 교육부문에 대한 투 자 확대를 촉구

\section{III. 관찰 및 평가}

ㅁ필리핀정부의 장기적 경제 안정을 위해서는 부가 가치세 인상 법안의 실행을 통한 세수의 확보로 재 정적자 폭을 감소시켜 2010년까지 균형재정을 이 루는 것이 아로요 정부의 중점 과제이나, 이에 대 한 대법원의 7 월 1 일자 부가가치세 인상법 시행 잠 정 보류결정으로 순조로운 달성이 십지 않을 것으 로 보이고 있음.

-페소화 및 증시는 상기 잠정보류 결정을 즉시 반 영하여 페소화 약세 지속 및 증시 급락 등의 불 안한 징후를 보임.

ㅁ 아울러 아로요 대통령에 대한 대선 선거조작 및 친 인척 비리 등 추문으로 정국이 혼란스러운 가운데 상기 개혁조치를 차질없이 수행하기는 어려울 것 으로 보이는 바, 향후 경제 개혁의 성공을 위해서 는 정국 혼란의 조기 수습 여부와 부가 가치세 인 상 잠정보류에 대한 법원의 신속한 조치가 관건이 될 것으로 보임.

[자료:주필리핀 대사관] 